\title{
For theory and its others: Comment on Jay
}

\author{
MICHAEL D. KENNEDY
}

The University of Michigan

When Theory and Society was founded, critical theory seemed to have surer footing and a grander vision. Martin Jay identifies an important shift away from grand theories and universalisms - whether naive or not - toward cynicism, ambiguity, and humility.

I find Jay's discussion to be extremely useful. By identifying Theory's "others" - both longstanding and new versions of Theory's alterities he elaborates clearly the various anti-theoreticist tendencies with which a Theory and Society community, or collegium, contends. With that elaboration, Jay can reconstruct the general ambition of a Reflexive Sociology or Critical Theory, moving it away from the grandiosity of Human Liberation toward a clarification of why Human Liberation is so hard to realize, and what more modest goals can take its place. This interest in dialogue is not so common, however.

Another strategy to be found in the critical tradition is to solidify the distinction between Theory and its others, and to homogenize those alterities under some general label of a postmodern relativism that is hubristic without accomplishment, trendy and politically irresponsible, and focused on localized forms of resistance with no sense of the larger historical and global transformations in which they are embedded. Of course, such an indictment works against the dialogue Jay seeks to cultivate. His attempt to establish the affinities of various self-identified forms of postmodernism with longstanding elements of the critical tradition - with Adorno's preponderance of the Object for instance should facilitate the engagement. But sometimes the commonalities, the link between theory and practice in both critical and more postmodern traditions for instance, heighten the tension. 
Much of cultural studies focuses on a particular form of practice, "resistance," but for many critics of cultural studies and postmodernism resistance is understood as retreat. If one can find resistance everywhere, how can one assess its consequence? To celebrate resistance, might we not be missing its systemically functional forms? Doesn't the focus on resistance distract us from questions of political strategy, mobilization, efficacy, and radical transformation? At the very moment capitalism is expanding, and a growing portion of the world's population is getting poorer and sicker, isn't the turn to resistance a turn away from emancipation, from the very combination of intellectual seriousness and political commitment that animated Theory and Society's founding? Isn't this a time for lament rather than celebration? Haven't we in fact regressed? One's answer to that question depends certainly on where one is now in the collegium, and where one has come from.

I am too young to have felt viscerally the exhilaration of a Theory defined by its commitment to emancipation. My critical sociology cut its teeth not on the New Left or Althusserianism, but on the 1980-81 Polish Solidarity movement, a movement whose emancipatory qualities are hard to deny, but whose spirit was grounded in pragmatic compromises with geopolitics, class alliances, and a vision of societal possibilities far more embedded in existing social relations than ones typically animating emancipatory visions. ${ }^{2}$ Thus, the postmodern humility and localism isn't so hard for me to digest, although I too have lamented Theory's departure from grand visions. That departure has opened the way for economists with a less than profound commitment to Critical Theory to influence disproportionately the reconstruction of postcommunist societies. ${ }^{3}$

Too, my experience in the academic world has not been one where Theorists and Postmodernists have been at each other's throats. The University of Michigan, for example, ${ }^{4}$ has had a tradition of dialogue across these positions of big historical theory and postmodern grounding that makes this difference merely one distinction among others, and the dialogue Jay seeks is a regular part of the conversation. In this winter 1995 term, for instance, the juxtaposition of political theorist Partha Chatterjee and his South Asian poststructuralism, Marxist anthropologist Terry Turner and his critical engagement with a praxis of human rights, historian Fred Cooper and his deconstruction of British and French discourses of development in colonized Africa, and Atina Grossmann and her analysis of the mass rape by Soviet soldiers of Ger- 
man women in the end of World War II illustrate the benefit of having both postmodernism and Theory alongside one another.

In short, the very dialogue Jay seeks to cultivate can be enormously productive and quite interesting, and by no means distracting from big historical questions. Indeed, it might actually help us move the discussion out of the ethnocentric position in which Theory can easily find itself, as he notes.

One of the most important transformations over the last twenty years has been of the Theory collegium itself. Certainly within the North American context, the racial, gender, and sexual identities of the Collegium have changed, at least in the larger community of Theory. One important question to consider is the extent to which Theory and Society has also changed, in terms of articles, thematic issues, editorial board membership, and conference participation.

In general, gender and sexuality certainly have become central features of much reflexive sociology and critical theory - from Joan Scott's famous essay on gender to Julia Adams's recent historical sociology of Dutch state formation. ${ }^{5}$ The recent collection on masculinities in Theory and Society also represents a major step forward in this elaboration of the reflexive project. ${ }^{6}$

Theories of race, ethnicity, and the nation have moved way beyond the 1960 s as well, especially in the analysis of popular culture. I think here of Robin D. G. Kelley's work on African-American popular culture and his contribution to a critical theory of race, ${ }^{7}$ of Paul Gilroy on the Black Atlantic, ${ }^{8}$ of Ina Merkel on East German identity formation, ${ }^{9}$ and of Chatterjee on the nation. ${ }^{10}$ The invocation of these last two works, however, illustrate another accomplishment in Theory, and one that is reflected unevenly in Theory and Society.

In Jay's essay, theory seems to exist without geographical grounding. The tone of his article seems rather oriented toward North American and West European academic space. Is that right? And if so, why and with what consequence? Addressing this question does not seem to be to be at all one of celebrating anti-theoreticism, but rather one establishing the conditions enabling the theoretical articulation of some problems rather than others. ${ }^{11}$ This is really important, especially if the contours of history are our main concern. 
Theorists sometimes contend that postmodernists focus too much on their own grounding and too little on the big questions. But the way in which this can be put suggests that the contours are easily seen, and that where one looks for Theory is obvious. For instance, one common refrain - which books situate the collapse of communism and the apparent victory of liberal capitalism? - is a good example of why we should ground our discussion of Theory. One can't go to Poland and much of the rest of Eastern Europe without being overwhelmed with the situating of communism's collapse and the victory of liberal capitalism. Of course, many of these of these might not count for reflexive sociology, much less Marxism or postmarxism, since many of these works are celebrations of the Fall and anticipations of how to make liberal capitalism work in postcommunism. But there are important exceptions, including those offered by authors who contributed to the special issue of Theory and Society on the Theoretical Implications of the Demise of State Socialism. ${ }^{12}$ But let me refer to one that did not.

Jadwiga Staniszkis ${ }^{13}$ is a good example of the Theory with a capital T coming out of Eastern Europe, that does just what many Theorists seek. Her most recent work, ${ }^{14}$ however, questions just what many Theorists take as a premise: that communism has ended and that liberal capitalism is its successor. Unless we want to have a simple indicator of communism, like central planning and communist party rule, ${ }^{15}$ the society made by communist rule continues to live and structure the options capitalism faces. ${ }^{16}$ And the capitalism that emerges is far from liberal, and is rather a new form of political capitalism based on its communist legacy. ${ }^{17}$

The quality of Theory - not only in terms of a mode of explanation and repository of theoretical tradition but especially in terms of the premise of questions - coming out of Eastern Europe is thus important for a Reflexive Sociology and Critical Theory grounded in Western Europe and North America to engage. Above all, it is tackling some of the big historical questions the critics of cultural studies seek, but without the normative commitments that typically mark critical theory and reflexive sociology. ${ }^{18}$

It is this kind of international exchange, entirely consonant with Jay's point about dialogue, that I see as an unambiguous step forward from the 1970s. Consider even the difference from the 1980 s - when I had to be the courier for the article by my Polish colleagues Grzegorz Bakuniak and Krzysztof Nowak that appeared in Theory and Society in 
$1987,,^{19}$ vs. the 1994 issue that was a real international collection. Geographically, then, it seems to me that Theory and Society is much broader than it once was.

Nevertheless, there are still geographical limits to this new exchange. I just want to point out one rather obvious one: that South Asian studies has developed a strong theoretical community that hasn't made it much into Theory and Society and is rather to be found in journals more connected to Anthropology than Sociology. ${ }^{20}$ What does that uneven geographical extension do to our theoretical dialogue, I wonder, and our sense of accomplishment?

These reflections lead me to appreciate even more Jay's account of Theory as a moment of reflexive self distancing, which necessarily engages its Others, its Alterities. To the extent we can make these engagements explicit, I believe we can recognize more clearly our progress, even if progress means a growth in humility. But it does not seem to me that humility necessarily undermines efficacy - the contribution of theory and intellectuals to praxis. It does, however, require a sense of liberation to become more problematic and multiple.

I should raise one additional point about our progress that doesn't so neatly fit in the general tension between Theory and its Others, but certainly is a mark of progress in reflexivity. Sociology at least has made incredible progress, if by that we mean that we have been able in the last two decades to become far more reflexive about our modes of explanation and the alternatives legitimately sociological. Here I think in particular about what has happened at my institution, and the appreciation for narrative and historical analysis that has been won by the likes of Janet Hart, Bill Sewell, and Peggy Somers. ${ }^{21}$

In the end, then, I feel like we've come a very long way. Alvin Gouldner's work was one of my principal inspirations when I began graduate school, and so I feel quite honored to be included at the conference commemorating his legacy in Theory and Society.

Gouldner's disposition to be a ridge rider between sociology and Marxism $^{22}$ can be neatly extended to ridge riding between Theory and its Others. To me, it seems to be a quite proper reincarnation of the founding reflexive ambition. But too, the elaboration of alternative methods within sociology and the elevation of race, ethnicity, nation, gender, and sexuality to key terms of the critical discourse are impor- 
tant developments that require further cultivation. Theory and Society's continued hospitality and further encouragement of these tendencies seem to be as important to the renewal of and critique in social theory as ridge riding and the explanation of history's contours or social totalities. But what of its connection to praxis? What of the relation between resistance and emancipation?

It seems to me that the social theorist can still be an agent of historical change, but in a totality more fragmented than ever. In part, this fragmentation is a consequence of the increasing reflexivity of social actors and not just of intellectuals. ${ }^{23}$ But the key problem is that this reflexivity is not linked, necessarily, to the emancipation that could at one time animate critical intellectuals in general. In some ways, the critical project must be as committed to explaining the relations among different forms of resistance as it is explaining variations in the power of movements and their link to the contours of history.

The variety of visions of the totality, the multiple expressions of identity, and the different claims to experience are necessarily part of the critical project today if practice is our commitment. Theory's engagement with this multiplicity, in the refashioning of our imagination of resistance and emancipation, is our opportunity. No doubt much of the identity formation through consumption - a theme frequently derided by a critical theory defined by its opposition to, rather than engagement with, cultural studies - is based on making culture for profit. But that is not all, especially if we are to give Kelley's work on AfricanAmerican urban youth or Merkel's on East German collective identity a serious reading. And without attention to such studies on the multiplicity of identity formations, critical theory will lose its potential link to praxis and become, once again, that isolated "flicker of hope" even as the social conflicts promising social transformations rage about it.

\section{Notes}

1. See the "Introduction" to Nicholas B. Dirks, Geoff Eley, and Sherry Ortner, Culture/Power/History (Princeton: Princeton University Press, 1994).

2. My first book, Professionals, Power and Solidarity in Poland: A Critical Sociology of Soviet-type Society (Cambridge: Cambridge University Press, 1991) is a reflection of this original engagement.

3. See my "Intellectuals, intellectuality and the restructuring of power relations after communism and modernity," CSST Working Paper \# 80, 1992.

4. Especially in the Program for the Comparative Study of Social Transformations (CSST). 
5. Joan Scott, "Gender: A useful category of historical analysis," American Historical Review 91/5 (1986): 1053-1075; Julia Adams, "The familial state: Elite family practices and state making in the early modern Netherlands," Theory and Society 23/4 (1994): 505-539.

6. "Masculinities," ed. R. W. Connell, Theory and Society 22/5 (1993).

7. See Race Rebels: Culture, Politics, and the Black Working Class (New York: Free Press, 1994); "Nihilists or stylists? Black urban culture and the predicament of social science," CSST Working Paper \# 103, 1993.

8. Black Atlantic: Modernity and Double Consciousness (Cambridge: Harvard University Press, 1993).

9. Ina Merkel, "From a socialist society of labor into a consumer society? The transformation of East German identities and systems," in Michael D. Kennedy, editor, Envisioning Eastern Europe: Postcommunist Cultural Studies (Ann Arbor: University of Michigan, 1994).

10. From his 1986 Nationalist Thought and the Colonial World (Zed Press) to his 1993 The Nation and Its Fragments: Colonial and Postcolonial Histories (Princeton University Press).

11. For instance, CSST has decided to focus on a theme next year of "Locating conservatisms." The motive for this question comes clearly from the North American and European experience, and it is therefore easy to identify visiting scholars who could address conservatisms in North America, the European Union, and the postcommunist world, but rather more difficult in the Latin American, African, and Asian contexts to recognize the concordance between the label and the phenomenon we hope to interrogate.

12. Volume $23 / 2$ (1994). This volume has very much a "cutting edge/recent developments" mood in the following senses: there are radically different analytical perspectives in the collection; some articles provide theoretical innovation relatively innocent of other work in area studies; and several pieces are arguments for explaining communism's demise based on extensions of paradigms developed for other fields of inquiry.

13. See her The Dynamics of Breakthrough in Eastern Europe (Berkeley: University of California, 1991); The Ontology of Socialism (Oxford: Oxford University Press, 1991); and others.

14. See her Working paper \#1 (1994) for the Advanced Study Center, the International Institute, the University of Michigan, and my interview with her in "Peripheral hybrids," Periphery: Journal of Polish Affairs \# 1, 19-21.

15. This is the premise for Andrew Walder's collection, The Waning of the Communist State: Economic Origins of Political Decline in China and Hungary (Berkeley: University of California Press, forthcoming). See the earlier version of his introduction in Theory and Society 23/2 (1994): 297-324, entitled "The decline of communist power: Elements of a theory of institutional change."

16. Edmund Mokrzycki makes this point in "Revenge of the Utopia," in Michael D Kennedy, editor, Envisioning Eastern Europe: Postcommunist, Cultural Studies (Ann Arbor: University of Michigan Press, 1994).

17. Ivan Szelenyi has also argued this in many of his recent papers. See his working papers (1994) for the Advanced Study Center, the International Institute, the University of Michigan.

18. Michael D. Kennedy and Naomi Galtz, "From Marxism to postcommunism: Socialist desires and East European rejections," Annual Review of Sociology (forthcoming). 
19. "The creation of collective identity in a social movement: The case of Solidarnosc in Poland," Theory and Society 16 (1987): 401-429. I brought its first version out in May 1984.

20. Examples include Public Culture and Comparative Studies in Society and History.

21. See, for instance, William Sewell, Jr. "Three temporalities: Toward a sociology of the event," in Terry MacDonald, editor, The Historic Turn in the Social Sciences (Ann Arbor: University of Michigan Press, forthcoming); Margaret R. Somers, "The narrative construction of identity: A relational and network approach," Theory and Society 23/5 (1994): 605-654; and Janet Hart, Gender and the War of Position: Nationalism and Resistance in Greece, 1941-1964 (Ithaca: Cornell University Press, forthcoming).

22. As Gouldner described his method in The Two Marxisms (Oxford University Press, 1980).

23. Scott Lash and John Urry's comment in Economies of Signs and Space (Sage Press, 1994) on the increasing capacity of actors to monitor their own conditions of action is a bit overoptimistic, but nonetheless a useful point to engage in a collegium concerned with reflexivity. 